\title{
PEMANFAATAN ANTIOKSIDAN (GLUTATHIONE) TERIPANG EMAS LAUT (GOLDEN STICHOUPUS VARIEGATUS) BERBASIS NANOTEKNOLOGI DALAM APOPTOSIS SEL SKUAMOSA KANKER MULUT
}

\author{
Miftakhul Cahyati*, Priska Anindhita A.R**, Nabilah Kusuma W.**, Sakinah Azzahra Adam** \\ *Departemen Penyakit Mulut Fakultas Kedokteran Gigi Universitas Brawijaya, Malang \\ **Program Studi Pendidikan Dokter Gigi Universitas Brawijaya, Malang \\ Korespondensi: Priska, Email: anindhitaar@gmail.com
}

\begin{abstract}
ABSTRAK
Kanker mulut adalah penyakit yang jarang diteliti dan kurangnya pendeteksian dini.. Antioksidan terbesar ada pada Teripang Emas Laut (Golden stichoupus variegatus) dengan bantuan Glutathione, memberikan elektron pada radikal bebas mampu menekan adanya kerusakan sel. Tujuan: untuk mengetahui dosis pemberian ekstrak Teripang Emas Laut (Golden stichoupus variegatus) yang paling efektif terhadap sel skuamosa kanker mulut. Metode: Tikus putih sebanyak 25 ekor: Tikus tanpa perlakuan, Tikus dengan induksi DMBA, Tikus dengan paparan DMBA (Dimethylbenz 7,12- $\alpha$ anthracene) $20 \mathrm{mg} / \mathrm{kg}$ BB diinduksi ekstrak teripang emas laut dosis 0,33 g/kg BB, 0,66 g/kg BB, dan 0,99 g/kg BB dengan analisa data One Way Anova. Hasil: K1 adalah perlakuan paling efektif. Hasil anova menunjukkan perlakuan $\mathrm{K} 1$ tidak berbeda signifikan dengan perlakuan $\mathrm{K} 2$, dan K3, maka ketiga perlakuan ini yaitu perlakuan K1, K2, dan K3 adalah perlakuan sama efektif. Kesimpulan: Tidak ada perbedaan signifikan diantara ketiga kelompok perlakuan.
\end{abstract}

Kata kunci: Sel skuamosa, Kanker Mulut, Teripang Emas Laut, Antioksidan. 


\title{
UTILIZATION OF ANTIOXIDANT (GLUTATHIONE) OF GOLD SEA CUCUMBER (GOLDEN STICHOUPUS VARIEGATUS) BASED ON NANOTECHNOLOGY IN APOPTOSIS OF SQUAMOUS CELL CARCINOMA
}

\begin{abstract}
Oral cancer is a disease that is rarely studied and lacks early detection. The biggest antioxidant is in Sea Gold Sea Cucumber (Golden stichoupus variegatus) with the help of Glutathione, giving electrons to free radicals to suppress cell damage. Objective: to determine the dose of the extract of Sea Gold Sea Cucumber (Golden stichoupus variegatus) which is the most effective against squamous cell cancer of the mouth. Methods: 25 white mice: Untreated rats, DMBA induction, Rats with DMBA (Dimethylbenz 7,12- a anthracene) exposure 20mg / kg BB induced sea cucumber gold sea cucumber dose $0.33 \mathrm{~g} / \mathrm{kg} \mathrm{BW}, 0,66$ $\mathrm{g} / \mathrm{kg} \mathrm{BW}$, and $0.99 \mathrm{~g} / \mathrm{kg}$ BB with One Way Anova data analysis. Result: K1 is the most effective treatment. ANOVA results showed that treatment $\mathrm{K} 1$ was not significantly different from treatment $\mathrm{K} 2$, and $\mathrm{K} 3$, then the three treatments, namely treatments $\mathrm{K} 1, \mathrm{~K} 2$, and $\mathrm{K} 3$ were the same effective treatments.
\end{abstract} Conclusion: There were no significant differences between the three treatment groups.

\section{PENDAHULUAN}

Masalah penyakit kanker di Indonesia hampir $70 \%$ ditemukan dalam keadaan stadium yang sudah lanjut bahkan meninggal dunia. ${ }^{1}$ Salah satu jenis penyakit kanker adalah kanker mulut sel skuamosa yang paling jarang diteliti dan kurangnya pendeteksian dini dan merupakan masalah serius di bidang kesehatan gigi dan mulut Indonesia selaku negara dengan mayoritas perokok. $^{2}$ Saat ini banyak dilakukan penelitian mengenai manfaat kandungan dari hewan, salah satunya adalah teripang. Teripang adalah hewan laut yang memiliki potensi ekonomi yang cukup besar karena mengandung berbagai bahan yang bermanfaat dan dapat dijadikan sebagai sumber protein hewani, obat luka dan anti inflamasi bahkan antikanker. ${ }^{3}$

Indonesia adalah negara pengekspor teripang terbesar di dunia. Tetapi, hanya sedikit masyarakat Indonesia yang mengetahui manfaat dari teripang. Kandungan teripang bermanfaat sebagai obat anti virus, anti mikroba, anti peradangan, kecantikan, meningkatkan imunitas, membantu pertumbuhan sel baru, dan sebagai anti kanker. ${ }^{4}$ Jenis teripang terbanyak adalah genus Holothuria diikuti oleh Stichoupus. Dengan mengkatalis Superoksida dan $\mathrm{H}_{2} \mathrm{O}_{2}$, kemudian direduksi menjadi GSH pada tubuh dan mampu menetralisir radikal bebas. Tubuh memerlukan 
GSH lebih dari luar tubuh, dari teripang emas laut (Golden stichopus variegatus) yang memiliki kandungan_asam amino tinggi 126-216 mg/g protein lebih tinggi dari kandungan hewan dan tumbuhan lainnya. ${ }^{5}$

Karena permasalahan tersebut kami berinisiatif untuk memanfaatkan ekstrak pada teripang emas laut terutama karena kandungan antioksidan (G/uthatione) yang besar dengan memanfaatkan nanoteknologi yang merupakan teknologi terbaru di bidang pengetahuan yang mengubah ukuran partikel menjadi nanometer sehingga obat atau zat lebih mudah diserap oleh tubuh. Tujuan dari penelitian ini adalah membuktikan keefektifan kandungan ekstrak kasar teripang emas laut (Golden stichoupus variegatus) berbasis nanoteknologi dalam jumlah penurunan sel skuamosa kanker mulut.

\section{METODE}

Penelitian ini mengunakan desain true experimental design in vivo laboratorium dan rancangan randomized post test only controlled group design. Penelitian dilakukan di Laboratorium Fakultas Kedokteran Gigi Universitas Brawijaya.

Sampel menggunakan 25 ekor tikus putih Rattus norvegicus galur wistar jantan yang dibagi menjadi 5 kelompok perlakuan yaitu K(-) dengan tikus tanpa perlakuan, $\mathrm{K}(+)$ dengan tikus paparan DMBA (Dimethylbenz 7,12- $\alpha$ anthracene) 20mg/kg BB, KE1 dengan tikus dengan paparan DMBA (Dimethylbenz 7,12- $\alpha$ anthracene) $20 \mathrm{mg} / \mathrm{kg}$ BB dan induksi ekstrak teripang emas laut dosis $0,33 \mathrm{~g} / \mathrm{kg} \mathrm{BB}$, KE2 dengan dengan tikus dengan paparanDMBA
(Dimethylbenz 7,12- $\alpha$ anthracene) 20mg/kg BB dan induksi ekstrak teripang emas laut dosis 0,66 $\mathrm{g} / \mathrm{kg}$ BB, KE3 dengan tikus dengan paparan DMBA (Dimethylbenz 7,12- $\alpha$ anthracene) $20 \mathrm{mg} / \mathrm{kg}$ BB dan induksi ekstrak teripang emas laut dosis $0,99 \mathrm{~g} / \mathrm{kg} \mathrm{BB}$.

Pengambilan sampel teripang emas laut diperoleh dari UD. Teripang Surabaya sejumlah 8 ekor dalam kondisi kering. Ekstraksi teripang menggunakan metode ekstraksi kering, maserasi. Teripang 4 ekor ditiriskan, ditimbang dengan berat 413 gram lalu dihaluskan dengan blender dan dimasukkan ke gelas kimia $1 \mathrm{~L}$ seperlima bagian. Pelarut methanol ditambahkan hingga volumenya mencapai $1 \mathrm{~L}$. Sampel dimasukkan ke dalam sonikator selama 1 jam dan dimaserasi 24 jam. Filtrat disaring dengan kertas saring Whatman no. 1. Proses maserasi diulang hingga filtrat yang diperoleh bening. Hasil filtrat diuapkan dengan alat rotary vacuum evaporator hingga lebih pekat dengan suhu $40^{\circ} \mathrm{C}$ dengan rotasi pemutaran round flask vol. 5. Hasil akhir adalah ekstrak kasar yang bebas dari pelarut dengan volume $20 \mathrm{ml}$. Nanopartikel yang dibuat dengan metode sonifikasi mengunakan alat ultrasonik kemudian didapatkan ekstrak kasar teripang emas laut yang telah disonikasi. ${ }^{6}$

Uji antioksidan menggunakan metode DPPH yang akan didapatkan ekstrak teripang yang memiliki kapasitas antioksidan tertinggi melalui penentuan Panjang gelombang maksimum, waktu kestabilan pengukuran antioksidan dan pengukuran mendekati nilai kapasitas antioksidan pembanding maka dapat dikatakan bahwa sampel berpotensi sebagai salah satu alternative antioksidan. 
Pembuatan larutan karsinogen yang dilakukan dengan melarutkan sejumlah tertentu serbuk DMBA(Dimethylbenz 7,12- $\alpha$ anthracene) ke dalam $1 \mathrm{ml}$ minyak jagung. Selanjutnya dilakukan proses homogenasi diaduk dengan pengaduk stirer selama 25 menit sampai larutan larut. Dosis induksi yang diberikan adalah DMBA $20 \mathrm{mg} / \mathrm{kg}$ BB pada tikus putih (Rattus norvegicus) berusia 4 minggu $2 \mathrm{kali}$ dalam seminggu selama 2 minggu. ${ }^{7}$ Mula mula tikus ditimbang untuk mengetahui volume larutan DMBA. Berat tikus rata-rata yang digunakan adalah 62 gram, sehingga perhitungan dosis yang diberikan pada tikus adalah :

$$
\begin{gathered}
\frac{20 \mathrm{mg}}{1000 \mathrm{~g}}=\frac{\mathrm{d}}{62 \mathrm{~g}} \\
\frac{20 \mathrm{mg} \times 62 \mathrm{~g}}{1000 \mathrm{~g}}=\mathrm{d} \\
1,24 \mathrm{mg}=\mathrm{d}
\end{gathered}
$$

Kemudian 1,24 mg DMBA ini dilarutkan dalam $1 \mathrm{ml}$ minyak jagung untuk diberikan dengan cara injeksi intra muskular pada daerah mukosa bukal. Setelah diberi perlakuan.

Induksi ekstrak kasar teripang emas laut sebelum diberi perlakuan, tikus putih ditandai dengan spidol untuk membedakan tiap perlakuan. Setiap perlakuan dilakukan dengan cara injeksi intralesi secara langsung ekstrak kasar dari teripang emas laut dengan dosis yang berbeda sesuai kontrol eksperimen mulai hari pertama hingga hari ketujuh.

Pengamatan sel yang mengalami displasia menggunakan pewarnaan $\mathrm{HE}$ dan digunakan mikroskop cahaya dengan perbesaran 4x. Analisa yang dilakukan adalah uji normalitas dan uji varian. Jika sebaran data normal dan varian data homogen, maka digunakan uji One Way Anova.

\section{HASIL PENELITIAN}
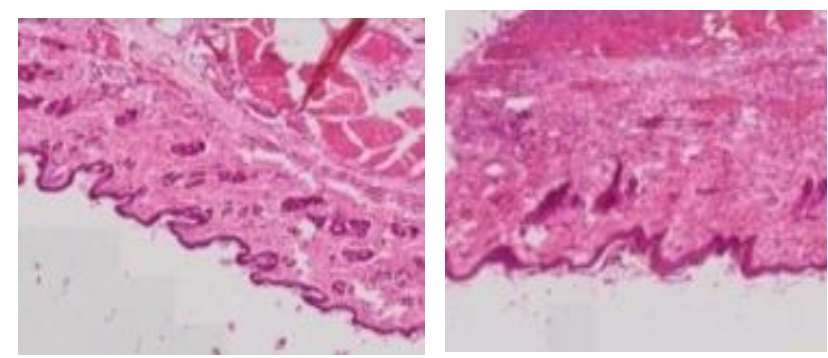

Kontrol Negatif

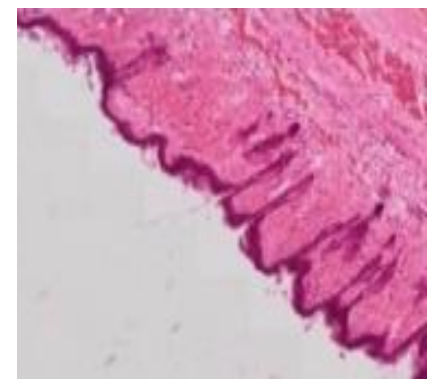

KP 1

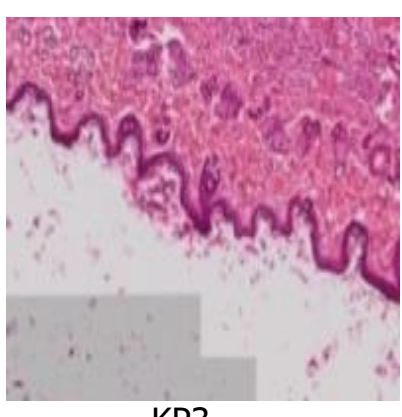

(2)

Kontrol Positif

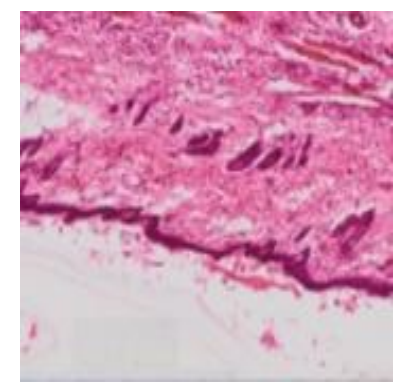

KP2

KP3

\section{Gambar 1. Hasil Pengamatan Mikroskopis Sel Epitel dengan Pewarnaan HE}
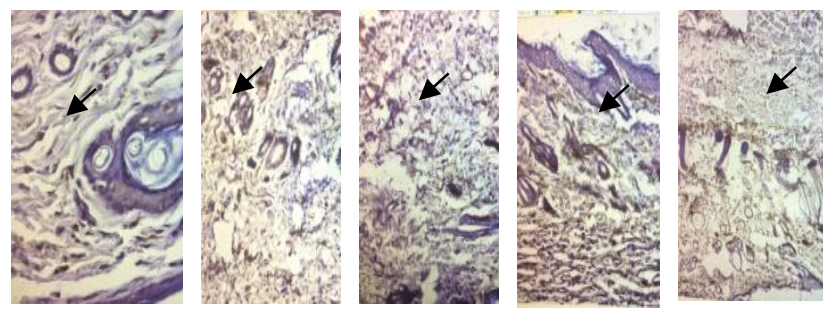
$\mathrm{K}(-) \quad \mathrm{K}(+) \quad \mathrm{KP} 1 \quad \mathrm{KP} 2 \quad \mathrm{KP} 3$

Gambar 2. Penampakan Mikroskopis oleh

Pewarnaan Imunohistokimia

\begin{tabular}{ccc}
\multicolumn{2}{c}{ Tabel 1. Nilai Rata - Rata Apoptosis pada } \\
& semua kelompok perlakuan \\
\hline No & $\begin{array}{l}\text { Kelompok } \\
\text { Perlakuan }\end{array}$ & $\begin{array}{c}\text { Nilai Rata - Rata } \\
\text { Apoptosis }\end{array}$ \\
\hline 1 & Kontrol Negatif & 0 \\
2 & Kontrol Positif & 0 \\
3 & Kelompok & 16,8 \\
& Perlakuan 1 & 31,8 \\
4 & Kelompok & \\
& Perlakuan 2 & 60,2 \\
5 & Kelompok & \\
\end{tabular}

\section{PEMBAHASAN}

Hasil pengamatan makroskopis adalah pada tikus tanpa diberi perlakuan apapun, penampakan pipi/ bukal secara makroskopis terlihat normal karena tidak terdapat perubahan bentuk, warna dan ukuran. ${ }^{8}$ Pada tikus dengan induksi DMBA/ zat karsinogen, penampakan pipi/ bukal secara makroskopis terlihat tidak normal karena terdapat perubahan ukuran, dan warna menjadi tidak segar. Pada tikus dengan induksi DMBA / zat karsinogen yang kemudian diberi perlakuan ekstrak kasar teripang dengan dosis 0,33 g/kg BB, penampakan pipi/ bukal secara makroskopis terlihat tidak normal, namun kondisinya lebih baik daripada kontrol +. Ukuran sel yang membesar berkurang. Pada tikus dengan induksi DMBA / zat karsinogen yang kemudian diberi perlakuan ekstrak kasar teripang dengan dosis 0,66 g / kg BB, penampakan pipi/ bukal secara makroskopis terlihat tidak normal, namun kondisinya lebih baik daripada kontrol + . Ukuran sel yang membesar berkurang signifikan. Pada tikus dengan induksi DMBA / zat karsinogen yang kemudian diberi perlakuan ekstrak kasar teripang dengan dosis 0,99 g / kg BB, penampakan pipi/ bukal secara makroskopis terlihat tidak normal, namun kondisinya lebih baik daripada kontrol +. Ukuran sel yang membesar berkurang paling signifikan.

Pada pengamatan mikroskopis, yakni pengamatan pada preparat dengan pewaranaan HE ditemukan perubahan pada epitel pipi tikus. Pada control negatif, epitel normal, tidak terjadi perubahan. Pada kontrol positif, terjadi banyak invasif sel basal di epitelium. Namun jumlah sel basal yang mengalami invasive tersebut mengalami penurunan setelah diberikan ekstrak Teripang Emas Laut. Semakin besar dosis ekstrak Teripang Emas Laut yang diberikan, semakin sedikit pula sel basal yang mengalami invasif seperti yang nampak pada Gambar 1.

Selain dengan pewarnaan $\mathrm{HE}$, dilakukan pewarnaan imunohistokimia untuk melihat apoptosis sel yang tidak normal. Sel yang mengalami apoptosis berwarna coklat dengan inti sel berwarna hitam seperti yang nampak pada Gambar $2^{6}$. Pada kelompok kontrol negatif tidak terlihat sel yang mengalami apoptosis dan apoptosis terbesar didapat pada kelompok perlakuan 3 dengan dosis $0,99 \mathrm{~g} / \mathrm{kg}$ BB yakni didapat rata -rata sebesar 60,2 butir pada satu lapang pandang seperti yang dijabarkan pada Tabel 1. 
Uji secara statistik didapatkan asumsi uji anova yaitu data normal serta variabel homogen dan dilakukan uji normalitas dan homogenitas varian hasilnya signifikan sehingga asumsi anova terpenuhi. Hasil uji anova menolak Ho yang artinya perbedaan rata-rata apoptosis pada setiap perlakuan.

\section{KESIMPULAN}

Dari data yang diperoleh dapat diambil kesimpulan bahwa ekstrak teripang emas laut (Golden stichoupus variegatus) berbasis nanoteknologi berpotensi dalam apoptosis sel skuamosa kanker mulut pada tikus putih (Rattus norvegicus) dibuktikan pada tabel nilai rata - rata ( Tabel 1. ) diatas yaitu rata rata tertinggi didapat dari pemberian ekstrak teripang dosis $0,99 \mathrm{~g} / \mathrm{kg}$ BB. Semakin besar dosis ekstrak teripang emas laut (Golden stichoupus variegatus) berbasis nanoteknologi maka semakin besar apoptosis sel kanker mulut pada tikus putih (Rattus norvegicus).

\section{DAFTAR PUSTAKA}

1. Natan Y, Uneputty PA, Lawerissa YA, Pattikawa JA. 2015. Species and size composition of sea cucumber in coastal waters of UN bay, Southeast Maluku, Indonesia. International Journal of Fisheries and Aquatic Studies. 2015; 3(1): 251-6.

2. Sirait AM. Faktor Resiko Tumor/ Kanker Rongga Mulut dan Tenggorokan di Indonesia (Analisis Riskesdas 2007). Media Litbangkes. 2013; 23(3): 122-9.

3. Linardi PJ, Damayanti MN, Cahyadi J. Perancangan Komunikasi Visual Pengenalan
Potensi Teripang. Jurnal DKV Adiwarna. 2014; 1(4): 1-13

4. Elfidasari D, Noriko N, Wulandari N, Perdan AT. Identifikasi Jenis Teripang Genus Holothuria Asal Perairan Sekitar Kepulauan Seribu Berdasarkan Perbedaan Morfologi. Jurnal Al Azhar. 2012; 1(3): 140-6.

5. Wijaya A. Radikal bebas dan parameter status antioksidan. Forum Diagnostikum. 1996; 1-12.

6. Kurniasari D, Atun S. Pembuatan dan Karakterisasi Nanopartikel Ekstrak Etanol Temu Kunci pada Berbagai Variasi Komposisi Kitosan. Jurnal Sains Dasar. 2017; 6(1): 315.

7. Adriansyah $\mathrm{H}$, Kamaludin MT, Theodorus, Sulastri H. Efek Hepatoprotektif Teripang Emas (Stichopus variegatus) pada Tikus Jantan Dewasa Galur Wistar yang Diinduksi Parasetamol Dosis Toksik. 2014; 46(2): 13643.

8. Fajrin M, Destiani D. Perancangan Sistem Pakar Diagnosis Kanker Mulut. Jurnal Algoritma. 2015; 12(1): 1-7. 